\title{
免疫組織化学で確診し得た鼻腔内悪性リンパ腫の一例
}

\begin{tabular}{|c|c|}
\hline 雄 (1) $^{-1}$ & 洋行 ${ }^{23) 3}$ • \\
\hline 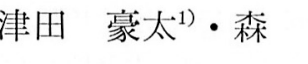 & 正樹 ${ }^{3)}$ - \\
\hline
\end{tabular}

\section{A Case of Nasal Malignant Lymphoma Confirmed by Immunohistochemistry}

\section{Nobuo Matsumoto, Hiroyuki Sugihara, Hitoshi Saito, Kenji Saito, Gota Tsuda, Masaki Mori, Norio Miyoshi and Masaru Fukuda \\ (Fukui Medical School)}

A case of malignant lymphoma localized in the left nasal cavity is reported. A 82-year-old man, who had been complaining: of left nasal obstruction, visited our hospital. His left nasal cavity was filled with a papillary tumor. Histologically, the first biopsy material was suggestive of poorly differentiated squamous cell carcinoma, but, the second biopsy material was diagnosed as malignant lymphoma. This may reflect the difficulty in histological differentiation between these tumors in hematoxylinand-eosin-stained sections. By an immunoperoxidase method, the tumor cells were found to be B-cells that produced $1 \mathrm{gM}$ with $\lambda$ type light chain.

Key words: malignant lymphoma, nasal cavity, immunohistochemistry

\section{はじめに}

頭頸部の悪性リンパ腫は病理組織学的に低分 化型扁平上皮癌との鑑別がしばしば困難であ る. 今回我々は鼻腔内に限局した比較的稀な悪 性リンパ腫の一例を経験し, 免疫組織化学的方 法によってその診断を確定し得たので, 文献的 考察を加光て報告する.

症例

患者：男性，82才.

主訴: 左鼻閉.

既往歴：心藏病 (10年前), 白内障（1 年前）

家族歴：特記事項なし

現病歴：昭和61年 8 月頃より両鼻閉を自覚. その後徐々に右鼻閉は改善したが左側は鼻呼吸 不能となり, 同年 9 月初旬に某病院を受診し,

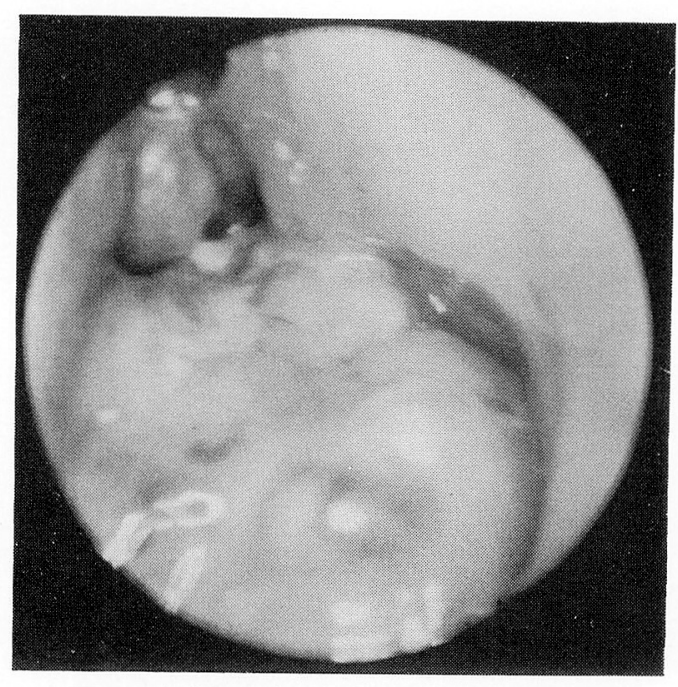

図！当科初診時の左鼻腔内写真 左鼻腔は乳頭状腫源で充満していた。

1）福井医科大学耳鼻咽喉科学教室

2) 福井医科大学第一病理学教室

3）福井医科大学附属病院検查部病理 
左鼾腔内腫瘍を指摘された，生検の結果，低分 化型扁平上皮癌の疑いの診断にて，同年 9 月 22 日，当科紹介となった。

現症 : 左鼻腔内は乳頭状腫瘍にて充満してい た（図 1 ）。左下鼻甲介は腫瘍により压排され て打り観察不能であった。左鼻漏あり。出血な し. 全身のリンパ節腫镺なし.

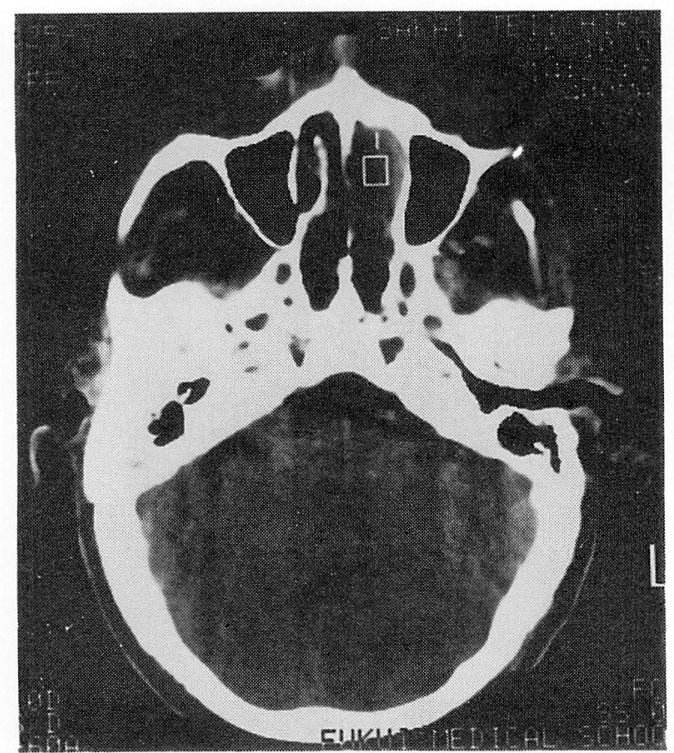

図 2 頭部 $\mathrm{CT}$

左具腔内に限局した軟性の組織塊を認めた。 骨破壊など認めず。

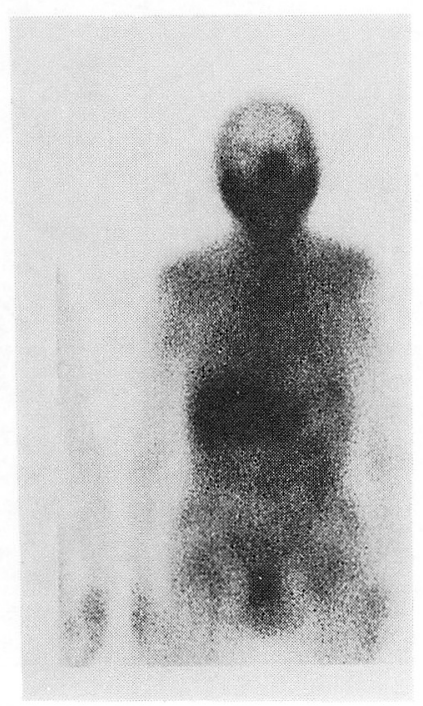

図 3 全身 $\mathrm{Ga}$ シンチ

左鼻腔内に Ga の異常集積を恝める他は， 特異な集積像を認めなかった。
検查所見：

鼻 X-P ; 雨上顎洞，穊骨洞に㓌影なし. 骨破壞なし.

頭部 CT ; 左鼻腔内に軟性の組織塊を認め た。但し左鼻腔内に限局しており, 骨破摔等は 認めなかった（図2 ).

胸部 X-P (単純, 断層); 右肺門部にリンパ 節腫脹が疑われた。

胸部 CT ; 右肺門部リンパ節腫脹なし.

全身 $\mathrm{Ga}$ シンチ; 左鼻腔内に $\mathrm{Ga}$ の異常集 積像を認める他は，正常でもみられる両下頭領 域，両頸部の集積を認めるのみであった。 な お，右肺門部リンパ節相当部位に集積はなかっ た（図 3 ).

リンパ管造影; 明確なリンパ節腫脹を認めず. 経過扣よび臨床診断: 初診時, 左鼻腔内は乳 頭状腫瘍にて充満して和り，完全鼻閉を生じて いた，再生検したところ，悪性リンパ腫の愁い の骖断を得た。昭和61年10月9 日上り放射線療 法 (4500 rad) 施行. $800 \mathrm{rad}$ 照射の時点で腫瘍 は 2/3に, $1200 \mathrm{rad}$ 照射の時点で $1 / 2$ に縮小し， $1800 \mathrm{rad}$ 照射で腫瘍はほぼ消失した（図 4 ）。

上述のごとく, CT, Ga シンチなどの検査所 見に上り，鼻腔内以外には病変を認めなかっ た。また，体重減少，発熱，盗汗などの全身症 状はなく, Stage IEA と診断された.

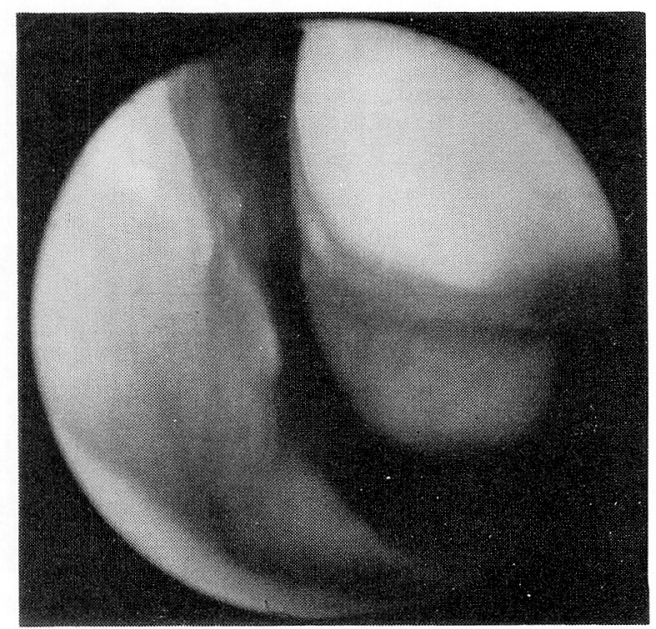

図 4 放射線治療 $4500 \mathrm{rad}$ 施行後の左筫腔内写真 腫瘍は完全に消失している. 


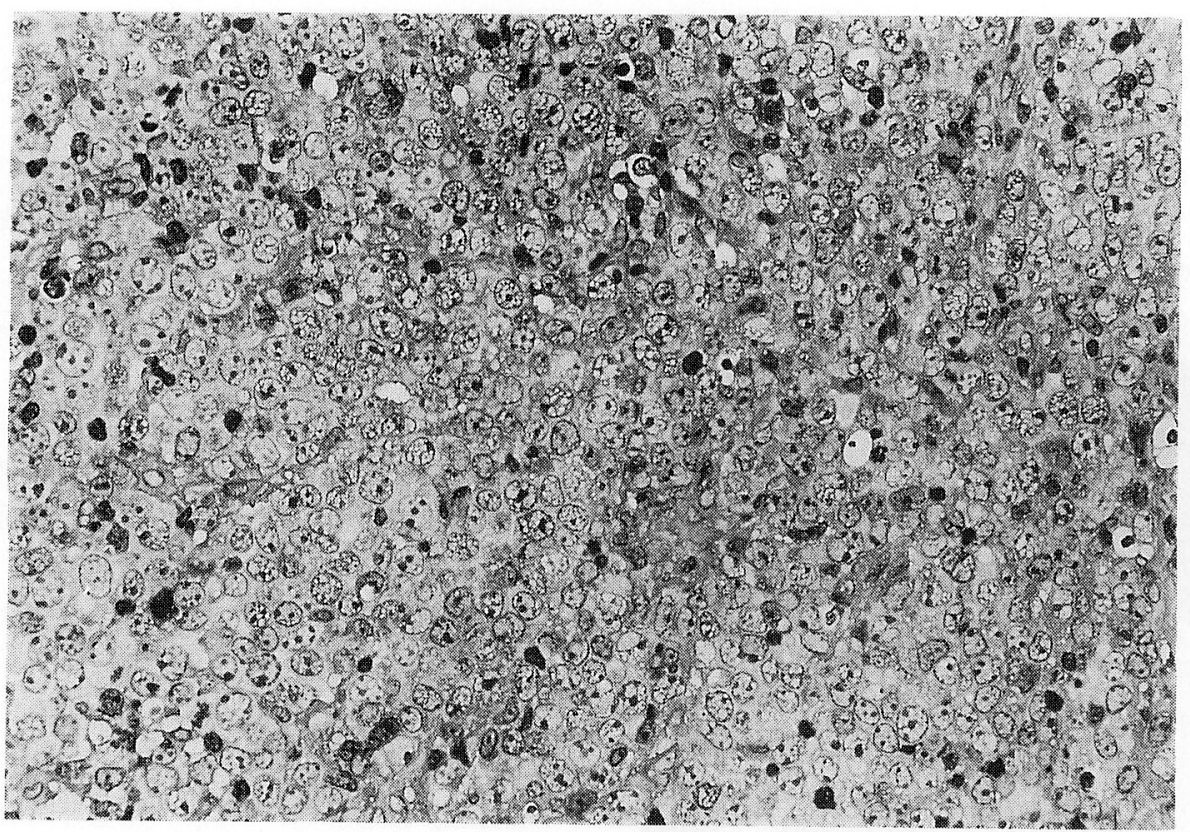

図 5 当科受診前, 某病院で生検した組織像 (H. E. 染色)

密に増生した細胞の境界が不明で，上皮性のシート状配列を思わせた。

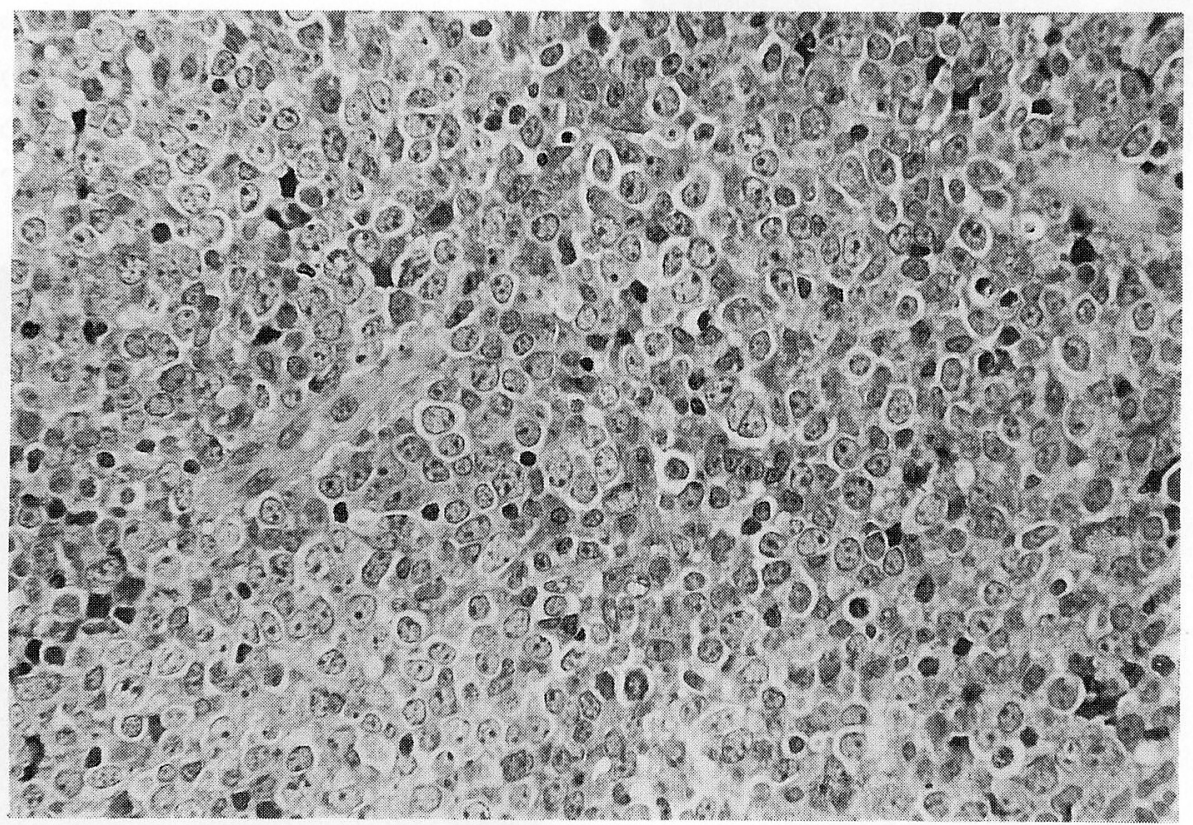

図 6 当科初診時生検した組織像 (H. E. 染色)

明嘹な核小体を持つ大型核と，好塩基性の胞体を有する円形細胞が主体を占めている. 

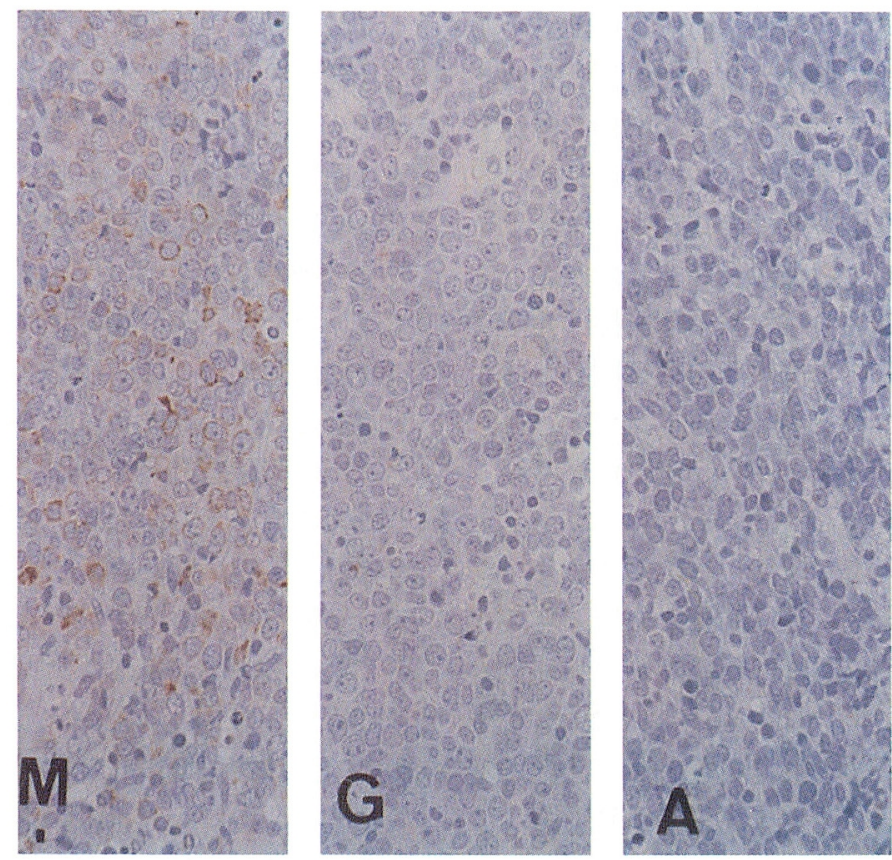

図 7 一次抗体として抗 $\operatorname{IgM}$ ，抗 IgG，抗 IgA 抗体を作用させた場合の 醉素抗体法の結果 (M, G, A はそれぞれ IgM, IgG, IgA を示ず) IgM で陽性 (褐色) で，IgG，IgA で陰性で边った。
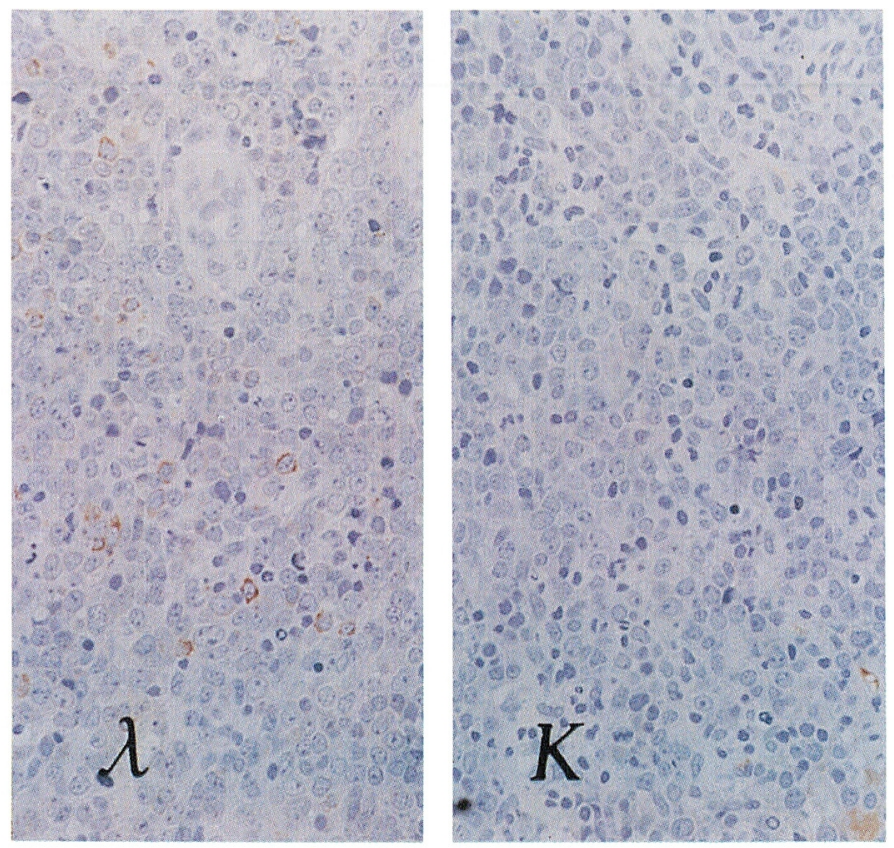

図 8 一次抗体として抗 , 抗 $\kappa$ 抗体䒚作用させた場合の酵素抗体法の結果 $\lambda$ で陽性で， $\kappa$ で㓌性であった。 
病理組織学的所見：当科受診前，某病院で生 検した組織像（図５）では，密に増生した細胞 の境界が不明で，上皮性のシート状配列を思わ せたため，低分化型扁平上皮癌が疑われた。し かし，悪性リンパ腫も否定できなかった。

当科初診時生検した組織像（図 6）では，上 皮様配列は見られず，明瞭な核小体を持つ大型 核と，好塩基性の胞体を有する円形細胞が主体 を占めていた. このことから，非ホジキン悪性 リンパ腫, diffuse, large cell type の疑いの診 断を得た。

そこで酵素抗体法 (ABC 法, ベクタステイン $\mathrm{ABC}$ キット $)^{1)}$ を用いて腫瘍細胞の晚疫グロブ リン産生の有無を調べると, 腫瘍細胞の一部が lgM 陽性で（図 7), light chain は, 入 type の み陽性であった（図８）。このことから，弾ク ローン性の免疫グロブリンを産生するB細胞性 のリンパ腫であることがわかった。
考察

耳鼻咽喉科領域では，低分化型扁平上皮癌と 悪性リンパ腫の鑑別がしばしば問題になる。こ れは頭頸部の悪性リンパ腫ではリンパ節由来の ものに比べて腫瘍細胞の境界が不鮮明で，核の 形も不整なことが多く2)，より低分化癌の形態 に近いために， HE 染色切片からだけでは両者 の鑑別が困難なことが多いからである。特に上 咽頭など，ワルダイエル輪から生じた腫瘍の場 合にこの問題に遭遇することが多い，本症例は 鼻腔内の腫瘍であったが，当初の生検で低分化 型扁平上皮癌が疑われ，二回目の生検では悪性 リンパ腫の疑いと診断された. 同じ腫瘍から採 取したにもかかわらず，一回目の生検組織では 細胞境界不明で，細胞がシート状に配列して見 え，二回目の生検組織ではバラバラの円形細胞 に見えた理由の一つに，組織の固定，包埋条件 の違いが考えられる.第一回目の生検組織はき わめて固定条件が良かったため，かえってリン

表 1 鼻腔腫瘍に占める扁平上皮癌と悪性リンパ腫の頻度

（文献 4 ）１3）より引用）

施設によりどちらが多いともいえない。

\begin{tabular}{|c|c|c|c|c|c|c|c|c|}
\hline \multirow{3}{*}{$\begin{array}{r}\text { 調查年度 } \\
1948-1968\end{array}$} & \multirow{3}{*}{$\begin{array}{l}\text { 施 設 名 } \\
\text { The Royal National } \\
\text { Throat, Nose and } \\
\text { Ear Hospital }\end{array}$} & \multirow{3}{*}{$\begin{array}{r}\text { 総計 } \\
636\end{array}$} & \multirow{3}{*}{$\begin{array}{r}\text { 良性 } \\
545\end{array}$} & \multicolumn{5}{|c|}{ 悪 } \\
\hline & & & & \multirow{2}{*}{$\begin{array}{l}\text { 計 } \\
91\end{array}$} & \multicolumn{2}{|c|}{ 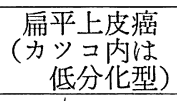 } & \multicolumn{2}{|c|}{ 悪性リンパ腫 } \\
\hline & & & & & 46 & $50.6 \%$ & 7 & $7.7 \%$ \\
\hline $1948-1974$ & $\begin{array}{l}\text { The Associated Royal } \\
\text { National Throat, Nose } \\
\text { and Ear Hospital }\end{array}$ & 790 & 672 & 118 & 34 & $28.8 \%$ & 4 & $3.4 \%$ \\
\hline $\begin{array}{l}\text { 戦後-1959.9 } \\
\text { (13年間) }\end{array}$ & $\begin{array}{c}\text { 癌研究会附属病院 } \\
\text { 放射線科 }\end{array}$ & 30 & 8 & 22 & 4 & $18.2 \%$ & 1 & $4.5 \%$ \\
\hline $1951.4-1967.3$ & 長崎大耳鼻科 & 22 & 9 & 13 & $\stackrel{2}{(1)}$ & $\begin{array}{l}15.4 \% \\
(7.2)\end{array}$ & 5 & $38.5 \%$ \\
\hline $1955-1980$ & 三重大耳鼻科 & / & ／ & 24 & 8 & $33.3 \%$ & 3 & $12.5 \%$ \\
\hline $1956.3-1968.2$ & 鹿児島大耳鼻科 & / & / & 14 & 0 & $0 \%$ & 4 & $28.6 \%$ \\
\hline $1957-1974$ & $\begin{array}{l}\text { 阪大耳鼻科 } \\
\text { 大阪回生病院耳鼻科 }\end{array}$ & / & I & 31 & 4 & $13 \%$ & 8 & $26 \%$ \\
\hline 不 明 & 酒井俊一自験例 & 111 & 35 & 76 & 5 & $6.6 \%$ & 12 & $16 \%$ \\
\hline $1966-1973$ & 東大耳鼻科 & 106 & 38 & 68 & $\begin{array}{l}37 \\
(6)\end{array}$ & $\begin{array}{l}54.4 \% \\
(8.8)\end{array}$ & 31 & $19.1 \%$ \\
\hline $1976.11-1986$. & 旭川医大耳鼻科 & 34 & 1 & 1 & 3 & $20 \%$ & 7 & $46.7 \%$ \\
\hline
\end{tabular}

（注）\%は悪性腫瘍の総数を母数とした。 
パ系細胞の特徵がわかりにくくなっていた可能 性がある。また，単クローン性の悪性リンパ腫 であっても，部位により組織像が微妙に異なる 場合があることも理由の一つと考学られよう。 このことは，HE 染色で雨者を鑑別することが いかにデリケートであるかを示している。

近年, 各種リンパ球の表面マーカーに対する 抗体が一般に使われるようになり，免疫組織化 学的にリンパ系細胞の同定ができるようになっ $た^{3)}$ 。また細胞質内に免疫グロブリンを証明す ることにより，B細胞であることを確認するこ とも可能となっている。 これらの方法により， 悪性リンパ腫と低分化型扁平上皮癌の鑑別がよ り確実にできるよらになったことは大きな進歩 である，本症例でも，酵素抗体法を用いて腫痬 細胞内に単クローン性の免疫グロブリンを証明 することによって, B-cell type 非ホジキンリン パ腫であることが確定できた。
鼻腔内の悪性腫瘍の頻度はかなり低い，東大 症例（1962-1973） ${ }^{4)}$ では, 頭頸部悪性腫瘍中, 鼻腔原発は $2.3 \%$ にすぎない。鼻腔悪性腫瘍の 統計については，現在までに数多くの報告があ り，その内訳も様々である．表１にその一部を

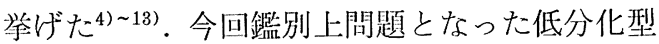
扁平上皮癌の形での報告は少ないので，扁平上 皮癌一般と悪性リンパ腫を比較検討したが，施 設によりどちらが多いともいえない状況であ る.

耳鼻咽喉科領域の節外性非ホジキンリンパ腫 の藏器別発生頻度の 現在までの 報告の一部を 表 2 に整理した2),14) 21). いずれの施設でも鼻 腔・副鼻腔原発のものは, ワルダイエル輪に比 ベればかなり少ない。また，鼻腔原発の非ホジ キンリンパ腫は，未梢 T細胞性の報告が多いよ らである. Yamanaka ら ${ }^{22)}$ は 7 例中, 本症例の ような $\mathrm{B}$ 細胞性は 1 例のみで， 6 例は $\mathrm{T}$ 細胞性

表 2 節外性非ホジキンリンパ腫の臓器別発生頻度（頭頸部）の報告例の集計

（支献 2），14） 21）より引用）

いずれの施設でも鼻・副鼾腔原発のものはワルダイエル輸原発のものよりかなり少ない.

\begin{tabular}{|c|c|c|c|c|c|c|c|c|}
\hline $\begin{array}{l}\text { 報 告 年 } \\
\text { (調 查 年) }\end{array}$ & $\begin{array}{lll}\text { 報 } & \text { 告 者 } \\
\text { (所 } & & \text { 属) }\end{array}$ & 鼻 腔 & 副奥腔 & ワ 輸 & 買・口腔 & 甲状腺 & 他 & 計 \\
\hline $\begin{array}{c}1972 \\
(1950-1964)\end{array}$ & $|c|$ & \multicolumn{2}{|c|}{33} & 199 & 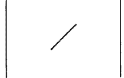 & 36 & & 268 \\
\hline $\begin{array}{c}1972 \\
(1957.4-1972.3)\end{array}$ & 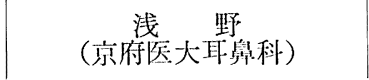 & \multicolumn{2}{|c|}{$4(2) 8$} & ～ & 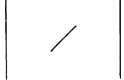 & 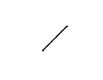 & & 14 \\
\hline $\begin{array}{c}1978 \\
(1965-1977)\end{array}$ & (鳥洅大谷 & 5 & 5 & 26 & & ／ & & 36 \\
\hline $\begin{array}{c}1980 \\
(1970-1979)\end{array}$ & (三㴈大耳鼻科) & 2 & 5 & 39 & \multicolumn{3}{|c|}{9} & 55 \\
\hline $\begin{array}{c}1983 \\
(1955-1980)\end{array}$ & $\begin{array}{l}\text { 毛利 } \\
\text { (東大病理) }\end{array}$ & \multicolumn{2}{|c|}{48} & 168 & & 16 & & 232 \\
\hline $\begin{array}{c}1983 \\
(1955-1979)\end{array}$ & $\begin{array}{c}\text { 䏱 内们 } \\
\text { (東医歯大放射線科) }\end{array}$ & 19 & ～ & 47 & 44 & *3 & 30 & 143 \\
\hline $\begin{array}{c}1985 \\
(1947-1983)\end{array}$ & Robbins & 5 & 33 & ／ & 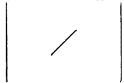 & / & & 38 \\
\hline $\begin{array}{c}1986 \\
(1969-1984)\end{array}$ & (国站がんセンター) & 18 & I & 66 & 3 & I & & 87 \\
\hline $\begin{array}{c}1987 \\
(1965-1985)\end{array}$ & （愛知がんセソター） & \multicolumn{2}{|c|}{21} & 119 & 2 & 14 & & 156 \\
\hline
\end{tabular}


であると述べている，その意味では本症例は稀 な例であるといえる。須知ら ${ }^{21}$ は，耳鼻咽喉科 領域に扮ける悪性リンパ在の多くは非ホジキン リンパ腫であり，その大部分が今回の症例のよ らなびまん性の typeであったと報告している. 非ホジキンリンパ腫に拈いては， I， II期のよ らな限局性の場合の治療は，その放射線高感受 性のため，3000-5000 rad の照射で腫瘍が消失 することが多く，従来放射線療法が中心であっ た. 近年，全身波及の予防のために化学療法が 併用されるようになってきた。 I 期のような限 局型の場合でも症例によっては全身波及が早 く, 放射線で局所は根治しても非照射部位に再 発を認めることがあるためである．現在行われ ている化学療法は, CHOP, VEPA, VEMP な どに代表される多剤併用療法であるが，特に VEMP 療法は, 鼻腔・副鼻腔などの限局例に 対しても単独で放射線療法に近い有效性が認め られており，寬解期間も長い。しかし副作用も 強く, VEMP より穏やかな治療法として mild VEP もある. 本症例では，82才といら高秢と， stage が IEA と早期であることを考光，結局 化学療法は行わなかった. しかし, 退院後約 1 年を経た現在再発なく，放射線治療後の口渴な ぞの弊害は多少あるが，日常生活には支障を来 していないまた従来，悪性リンパ腫は系統的 疾患であるといら考方方から，手術療法は禁忌 とされてきた，しかし，局所に限局した症例に ついては手術・放射線併用療法が有効であった といら報告も少なからずある(15),23),24).

今回鑑別の詨像となった低分化型扁平上皮癌 も, 悪性リンパ腫には劣るものの, やはり高放 射線感受性であり, 限局型の症例では, 放射線 治療単独で消失することもある. 悪性リンパ腫 との治療の違いは化学療法にある。第一に薬郕 の違いであり，低分化型扁平上皮癌ではテガフ ールなどを用いる，第二に，悪性リンパ腫にお けるほど化学療法は有効ではない。そのため, 一般には放射線治療と手術が併用される，化学 療法剂の局所動注（本症例のような下鼻甲介よ
り発生したと思われるものでは顎動脈ないし外 頸動脈への動注）が併用されることも多い。つ まり悪性リンパ腫とは異なり，あくまで局所制 御に主眼が置かれているのである.

悪性りンパ腫と低分化型扁平上皮癌はともに 放射線感受性が高いが，このように基本的な治 療方針は異なっている，本症例のように通常の $\mathrm{HE}$ 染色切片で鑑別の容易でない症例には積極 的に免疫組織化学的方法を用い，いずれである かを確認することがより適切な治療と予後の向 上のために不可欠であると考えられる。

鼻腔内腫瘍の特徴は比較的早期にみつかる場 合が多いことである。片側性，進行性の鼻閉， 鼻出血，血性番漏などの自覚症状が早期に現 れ，その診断も鼻鏡所見のみで容易なことが多 い. 本症例のようなび慢性大細胞型の悪性リン パ腫は悪性リンパ腫の中では比較的予後が悪い とされている25)。しかし，鼻腔では早期にみつ かることが多いので，大細胞型でも他の型と大 きな予後の差はないと思われる。本症例もI期 であることから，良好な予後が期待される18).

\section{まとめ}

82 才男性の左鼻腔内に発生し, 組織学的に低 分化型扁平上皮癌との鑑別が困難であった悪性 リンパ腫を，免疫組織化学的方法により確診 し，良好な治療効果を得たので，文献的考察を 加光て報告した。

木論文の要旨は第 2 回日本耳鼻咽顺科学会福井県地 万部会においてロ述した。

\section{参考文献}

1) $\mathrm{HSu} \mathrm{S}-\mathrm{M}$, Reine $\mathrm{L}$ and Fanger $\mathrm{H}$ : Use of avidin-biotin-peroxidase complex $(A B C)$ in immunoperoxidase techniques; a comparison between $\mathrm{ABC}$ and unlabeled antibody (PAP) procedures. J Histochem Cytochem $29: 577 \sim$ 580, 1981.

2）野口雅之, 渡辺 昌: Waldeyer 輪および鼾腔・

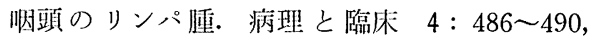
1986.

3 ）下山正德，潜 啓輔，飛内䝨正，他：リンパ系隀 
瘍細胞の膜表面形質. 内科 MOOK 17. 悪性リン ハ腫 (阿部正和, 尾前照雄, 河合忠一編). 45 55頁, 金原出版, 東京, 1982.

4) 森田 守: 鼻, 副鼻腔腫瘍. 臨木耳鼻咽喉科学 3 (沢木修二，設楽哲也，野村恭也編），225～299面， 中外医学社, 東京, 1980 .

5) Harrison D F N : Tumours of the nose and paranasal sinuses. Scott-Brown's Diseases of the ear, nose and throat (ed by John Ballantyne and John Groves). pp 299 330, Butterworths, London, 1971.

6) Friedmann I: Tumours of the nose and sinuses-material and classification. Pathology of Granulomas and Neoplasms of the Nose and Paranasal Sinuses. pp 100 102, Churchill Livingstone, Edinburgh London Melbourne and New York, 1982.

7 ）小林秀夫，永瀨邦彦：鼻腔，副鼻腔腫瘍の統湖的 観察. 耳展 3:470 477, 1960.

8 ）隈上秀伯：鼻腔腫瘍の儖林的観察. 耳喉 $40: 381$ 〜388, 1968.

9 ）浜口富美, 三吉康朗, 坂倉康夫，他：自副鼻腔悪

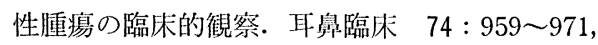
1981.

10）久保隆一，松村益美，大野政一：固有自腔より発 生した悪性腫瘍 14例について。耳鼻 16:151 155, 1970.

11）酒井俊一，尾崎正義，池田 宽，他：鼻・副鼻腔 悪性腫瘍 908 例の 観察. 耳盼. 21：859〜884, 1975.

12）酒井俊一：鼻・副鼻腔の隀瘍. 臨床耳鼻咽喉科頭 頸部外科全書（日野原正, 槜 学, 水越 治他 編). 21 81頁, 金原出版, 東京, 1985.

13）渡 昭仁，高橋光明，川䏱真一，他：舆腔腫炀34 例の検討. 耳奥臨木 補15:115～122，1987.

14) Freeman C, Berg J W, Culter S J : Occurrence and prognosis of extranodal lymphomas. Cancer $29: 252 \sim 260,1972$.
15）浅野 登, 斎藤 等, 松岡秀樹 : 鼻副鼻腔悪性り ンパ董の教室集計より見た治療指針.耳鼻臨床 $65: 1243 \sim 1255,1972$.

16）涌谷忠雄, 小林仁和, 清水友収, 他 : 細網肉腫の 治療成績一とくにその治療方針について一. 耳喉 $50: 29 \sim 33,1978$.

17）浜口幸吉, 坂倉康夫, 鵜飼幸太郎, 他 : 鼻副鼻腔 覀性リンパ廆 7 症例の検討. 耳鼻臨床 $73: 1447$ $\sim 1456,1980$.

18）䏱内澋一：リンパ節外性リンパ瘇. 内科シリーズ 39. 覀性リンパ董のすべて (坂野輝夫編). 204〜 214頁, 南江堂, 東京, 1983.

19）毛利昇, 島峰徹朗：節外性 non-Hodgkin リン 冺重. 日本臨床 41:2569 2577, 1983.

20) Robbins K T, Fuller L M, Vlasak M, et al : Primary Lymphomas of the nasal cavity and paranasal sinuses. Cancer $56: 814 \sim 819,1985$.

21）須知泰山, 本告 匡, 長谷川かをり, 他 : 節外性 リンパ隀の病理学的特徵. 病理と臨床 $4: 475 \sim$ 479, 1986.

22) Yamanaka N, Harabuchi V, Sambe S, et al : Non-Hodgikin's lymphoma of Waldeyer's ring and nasal cavity. Clinical and immunologic aspects. Cancer $56: 768 \sim 776,1985$.

23) Diamond H D : Clinical indications for the use of Nitrogen Mastard and Triethylene Melamine in Malignant lymphomas and Leukemias. Ann New York Acad Sci 68 : 974 978, 1958.

24）入江英雄, 村上晃一, 他 : 悪性リンパ隀の放射線 治療成績. 日本医放会誌 $28: 1232 \sim 1233,1968$.

25）尾山 淳, 太田和雄: 予後を左右する因子. 内科 Mook 17. 悪性リンパ腫（阿部正和，尾前照雄， 河合忠一編). 207 214頁, 金原出版, 東京, 1982.

$$
\left(\begin{array}{l}
\text { 別刷請求先 : 松本順雄 } \\
\text { 厂910-11 福井県吉田郡松岡町下合月 } 23 \\
\text { 福井医科大学耳鼻咽喉科学教室 }
\end{array}\right)
$$

